\title{
CULTURAL STUDIES ON LEPTOSPIRAE
}

\section{ON A FACTOR FOR COLONIAL GROWTH OF LEPTOSPIRAE}

\author{
Ryo Yanagawa, Takashi Hiramune and Susumu Ishir \\ National Institute of Animal Health, Tokyo
}

(Received for Publication Jan. 14, 1959)

\begin{abstract}
Colonial growth of leptospirae on solid medium, which has been the subject of study, was reported by Cox and LARson ${ }^{2)}$ in 1957. BAUER and MORSE ${ }^{1)}$ described, however, that Cox's solid medium failed to support the growth of the L. pomona which were used in their experiments. Negative results were also frequently obtained in this laboratory on the same medium. From these findings it is indicated that the factors necessary for the colonial growth of leptospirae are still worthy of controlled study.

A unique growth of leptospirae in a semi-solid medium was first described by Dinger ${ }^{4)}$ in 1932, and was referred to as Dinger's phenomenon by Czekalowski ${ }^{3)}$ who studied this phenomenon in further detail. This phenomenon is considered to be an expression of the microaerophil behavior of leptospirae. LAWRENCE ${ }^{5)}$ described the suitable range of oxygen for the growth of leptospirae in semi-solid medium.

An attempt has been made by the present authors to apply microaerophil incubation for the colonial growth of leptospirae on solid medium. The present paper describes the results of the experiments concerned.
\end{abstract}

\section{MATERIALS AND METHODS}

Medium: Cox's solid medium without sheep hemoglobin was used in this experiment.

Strains: Strain TR-1 (L. icterohaemorrhagiae), which was isolated in 1956 from a rat by Dr. Yамамото of the University of Tokyo, and strains Asakawa (L. icterohaemorrhagiae), Akiyami A (L. autumnalis), Akiyami B (L. hebdomadis), Akiyami C (L. australis-A), Moscou $\mathrm{V}$ (L. grippotyphosa) and Utrecht (L. canicola) were all supplied by Dr. Yамамото. Strain Mikawashima (L. icterohaemorrhagiae) has been preserved through guinea pigs, and was supplied by Dr. KITAOKA of the National Institute of Health. Strain Kyoto (L. hebdomadis), which was isolated from cattle in 1951 by Dr. WATANABE of the National Institute of Animal Health, strains Saeki, Aya-1, Okada (L. autumnalis) and strain Kimura (L. australis- $A$ ), which were recently isolated from cattle by Dr. KITA of the Chugoku Regional Laboratory of the National Institute of Animal Health, strains Suis S. R. (L. pomona) and Semarang (L. semaranga) were supplied by Dr. KItA. Strain Fujiwara (L. autumnalis) was isolated in 1953 from cattle by one of the authors.

Inoculation: Leptospiral cells, ranging in number from 30 to 150, were obtained by decimal dilution of the original culture. These cells, which were suspended in $0.1 \mathrm{ml}$ of Cox's liquid medium, were poured by pipette onto the solid medium and spread by tilting the plates by hand. The number of cells in the original culture was counted by the counting chamber as previously reported ${ }^{6}$. The agar plates were then preliminarily incubated at $37^{\circ} \mathrm{C}$ for about 2 hours.

Microaerophil incubation: Microaerophil incubation was carried out in the dessicators in which 1,3 and $5 \% \mathrm{CO}_{2}$ were supplied by Kipp's apparatus, respectively, or by closing 
the dishes with plasteline. They were incubated at $28 \pm 1^{\circ} \mathrm{C}$.

\section{RESULTS}

\section{Effect of microaerophil incubation on colonial growth of leptospirae}

Effects of various conditions of atmosphere on the colonial growth of leptospirae are summarized in Table 1.

Five strains of L. autumnalis were examined. Colonies of strain Akiyami A were developed in air, closed dishes, and in 1, 3 and $5 \% \mathrm{CO}_{2}$, respectively, although the colonies could do better in $\mathrm{CO}_{2}$. Colonies of strain Fujiwara hardly developed aerobically, but showed a good colonial growth in closed dishes and in 1,3 and $5 \% \mathrm{CO}_{2}$. Three other strains (strains Saeki, Aya-1 and Okada) failed to form colonies in air and in closed dishes. Colonies of these 3 strains developed only in 1,3 and $5 \% \mathrm{CO}_{2}$. A supply of a small amount of $\mathrm{CO}_{2}$, therefore, proved favorable for the colonial growth of $L$. autumnalis.

Colonies of 3 strains of $L$. icterohaemorrhagiae, on the contrary, never developed under a supply of more than $3 \% \mathrm{CO}_{2}$. Colonies of strain Asakawa developed in air, closed

Table 1. Effect of Various Atmosphere on Colonial Growth of Leptospirae

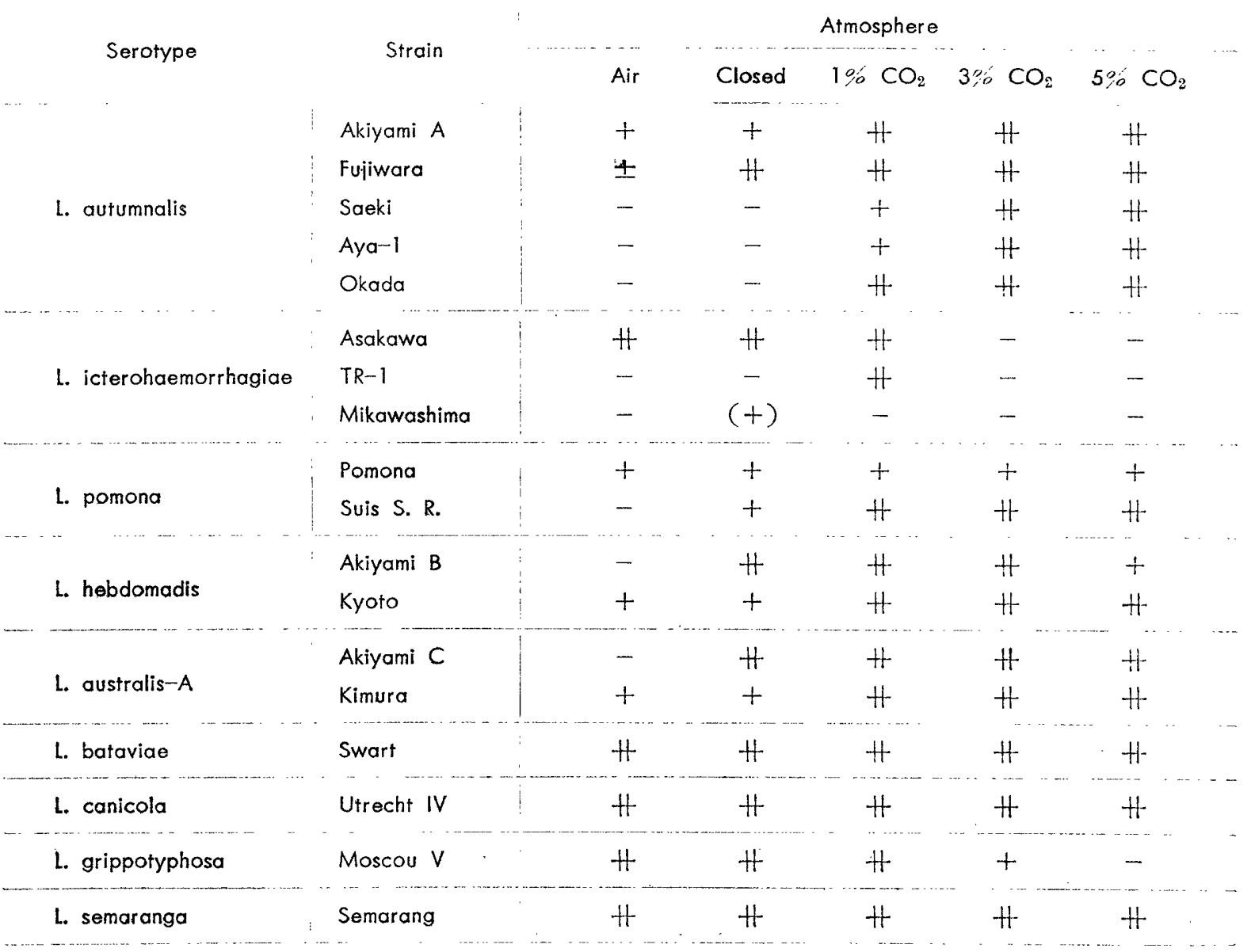

Leptospiral cells ranging in number from 30 to 150 were inoculated on each plate. Observed for three weeks.

Key: \# Distinct and sufficient colonial growth.

+ Colonial growth with delay or insufficient in number.

$(+)$ inconstant colonial growth.

\pm Slightly whitish turbidity but failed to develop into a colony.

- Negative growth. 
dishes and $1 \% \mathrm{CO}_{2}$. Strain TR-1 developed only in $1 \% \mathrm{CO}_{2}$, and strain Mikawashima developed only once in closed dishes. The colony of the last strain, which had been preserved through guinea pigs, was observed very close to the colonies of certain bacteria which had fallen on the same medium by accident.

L. pomona was examined with 2 strains. Colonial growth of strain pomona was observed under both aerophil and microaerophil conditions, strain Suis S. R. in closed dishes, and 1,3 and $5 \% \mathrm{CO}_{2}$, but not in air.

$L$. hebdomadis and $L$. australis- $A$ were examined with 2 strains each. Colonies of strains Akiyami B and Akiyami $\mathrm{C}$ developed in air, while those of strains Kyoto and Kimura failed to develop under the same condition. Colony formation of the latter 2 strains was accomplished in closed dishes or in 1,3 and $5 \% . \mathrm{CO}_{2}$. Supply of a small amount of $\mathrm{CO}_{2}$ proved favorable for the colonial growth of the strains of these types.

Colonial growth of strain Moscou V was accomplished in air, closed dishes and $1 \%$ $\mathrm{CO}_{2}$, but was retarded in $3 \%$ and not developed in $5 \% \mathrm{CO}_{2}$.

Colonial growth of strain Swart, Utrecht IV and Semarang could be observed under both aerophil and microaerophil conditions.

Colonial growth of leptospirae was constantly more successful under the microaerophil condition than in air, as a whole. Patterns of suitable microaerophil conditions, however, presented differences among strains.

\section{Effect of various microaerophil incubations on the colony type of leptospirae}

Colonies of leptospirae were thinner than those of other species of bacteria. Round or almost round colonies were usually 'developed, while mosaic (strain Moscou V) and small or pin-head (strains Asakawa, Swart and Utrecht IV) colonies were also observed. These colony types were considered specific to each of the strains. But the size of the colonies was frequently influenced by various microaerophil conditions. In general, colonies were large and thin in air but became smaller and thicker under the microaerophil condition as the $\mathrm{CO}_{2}$ concentration increased. Colonies of strain Semarang, especially, spread together on the whole agar medium in air but remained separate in 3 or $5 \% \mathrm{CO}_{2}$ (Figs. 5 and 6).

\section{Characteristic location of leptospiral colony on solid medium}

Leptospiral cells were always put on the solid medium in this experiment. Section of a colony showed that the leptospirae proliferated hemispherically into the agar medium but not on the medium (Fig 4). Spherical colonies were observed in the medium when the same medium was inoculated with leptospirae. Such conditions and shapes of the colonies were sufficiently specific to leptospirae and were observable irrespective of microaerophil or aerophil incubations or of the agar content of the medium.

Examinations on other factors

Through the use of agar from a certain origin, colonial growth of leptospirae was extraordinarily inhibited. The quality of the agar may be important for the colonial growth of leptospirae.

Rabbit serum was added to the solid medium so as to give it a 1,2,5 and $10 \%$ serum content. Colonial growth of leptospirae was observed in medium of 5 and $10 \%$ serum content but not in that of 1 and $2 \%$ serum content.

Horse and cattle sera failed to substitute that of the rabbit.

\section{DISCUSSION}

Colonial growth of leptospirae was almost constantly successful when the incubation was done under the microaerophil condition. Furthermore, colonies were usually clearer 
under the microaerophil condition than under the aerobic one. Microaerophil incubation seemed to be especially necessary if a small number of leptospiral cells were inoculated on the solid medium. Attention has been paid in this experiment to inoculate a small number of leptospiral cells on agar medium in order to make the individual colonies clearly distinguishable and to observe the exact patterns of microaerophil character of each strain.

Patterns of the suitable microaerophil conditions present differences among strains. For successful colonial growth, suitable microaerophil condition should be adopted for each strain. Colonial growth of $L$. autumnalis was usually accomplished in a small amount of $\mathrm{CO}_{2}$, while that of $L$. icterohaemorrhagiae was inhibited under a supply of more than $3 \%$ $\mathrm{CO}_{2}$. Strain Mikawashima, which has been passed through guinea pigs for maintenance of virulence, usually failed to form colonies. Colonial growth of this strain was observed only once in closed dishes, very close to the colonies of certain other bacteria. Possible effects of other species of bacteria on the growth of leptospirae is worthy of precise study.

The characteristic features of colonial growth and the hemispherical figure of the colonies are considered to be unique to leptospirae. Proliferation of leptospirae seemed to be possible only in but not on agar medium. On the other hand, colonies of other species of bacteria usually develop densely on agar medium. These findings may be the marked differences between the colonies of leptospirae and other species of bacteria. The characteristics of the leptospiral colony are considered to have a possible relationship with Dinger's phenomenon. These findings are useful, in practice, for differentiating the colonies of leptospirae on the solid medium from those of other species of bacteria.

\section{SUMMARY}

The successful colonial growth of leptospirae was accomplished with many strains under the microaerophil condition. The colonial growth was more distinct under the microaerophil condition than under the aerophil one, although the colonies of some strains developed aerobically.

Patterns of suitable microaerophil conditions present differences among strains. Strains of the same serotype occasionally showed different microaerophil character. Specific range of $\mathrm{CO}_{2}$ requirement was observed in certain serotypes. Of the 5 strains of $L$. aulumnalis, 4 formed colonies only in a small amount of $\mathrm{CO}_{2}$. Colonial growth of L. icterohaemorrhagiae usually succeeded in closed dishes or in $1 \% \mathrm{CO}_{2}$ and not under a supply of more than $3 \% \mathrm{CO}_{2}$.

The colony type of many strains was usually round, while mosaic or pin-head colonies were observed in some strains. These were considered specific to each strain. Size or figure of the colony of same strain, however, varied with the atmospheric condition. Generally, colonies were larger and thinner in air, while they were smaller, thicker and clearer under the microaerophil condition as the $\mathrm{CO}_{2}$ concentration increased.

Leptospiral cells proliferated hemispherically into the solid medium and never on the surface of the medium, irrespective of aerophil or microaerophil incubations or of the agar content of the medium. The characteristic development and figure of the colonies were sufficiently specific to leptospirae.

From these findings, microaerophil incubation is considered to be one of the most important factors for the colonial growth of leptospirae.

\section{AGKNOWLEDGEMENTS}

Acknowledgements are due to Dr. Yamamoto of the University of Tokyo, Dr. KitaokA of the National Institute of Health, and Dr. KITA of the Chugoku Regional Laboratory 
of the National Institute of Animal Health, for so kindly supplying the strains of leptospirae, and to Drs. Fujita and Shibata of the National Institute of Animal Health for their very valuable advice.

\section{REFERENCES}

1) BAUER, D. C. and E. V. Monse: Proc. Soc. Exp. Med. \& Biol., 98, 505 (1958).

2) Cox, C.D. and A.D. LARSON: J. Bact., 73, 587 (1957).

3) Czekalowski, J. W., MCLeod, J. W. and J. RodicaN : Brit. J. Exp. Path., 34, 588 (1953).

4) DiNGER, J. E.: Geneesk. Tijdschr. Ned-Ind., 72, 1951 (1932). (cited in 3).

5) Lawrence, J.J.: Austral. J. Exp. Biol. \& Med. Sci., 29, 195 (1951). [Biol. Abst., 26, 846 (1952).]

6) Yanagawa, R., Shimizu, T., Hiramune, T. and S. Ishit : Bull. Nat. Inst. Animal Health, No. 36, 28 (1958).

\section{レプトスピラの培養に関する研究}

II. 集落形成のためのひとつの条件について

梁川良・平棟孝志 - 石井進 農林省家畜衛生試䮖場

（昭和 34 年 1 月 14 日受付）

レプトスピラの集落形成を確実にする目的で，わ つが螊気的な状態で培養をこころみた。その結 果, 好気性培㗇では集落を形成しない菌株でも集落 を形成するようになり，また好気性に発育する菌株 でも，このように培湌する方がより明膫な集落をつ くることを認めた，至適嫌気度は菌株によって異る から，それぞれの菌株に適した大気の状態を与える ことが，レプトスピラの集落形成に必要な条件であ ると考えられる.

同じ菌型に属する菌株でも, 至適嫌気度は必ずし も同じくない，しかしある程度の共通性が認められ る場合もある.たとえばL. autumnalisに属する菌 株は， 1 乃至 $5 \%$ の $\mathrm{CO}_{2}$ 分圧下で最もよく集落を 形成する.また，L. icterohaemorrhagiae に属する 菌株は, $3 \%$ 以上の $\mathrm{CO}_{2}$ 分圧下では集落形成を抑 制され，密閉したシヤーレの中か，または $1 \% \mathrm{CO}_{2}$ 分圧下が集落形成に最も適しているように認められ た。

集落の形は，多くの菌株では円形または概ね円形
であるが，モザイク状または極めて小型のものも 認められた.これらの形はそれぞれの菌株に特異的 と考えられる. また同じ菌株でも, 大気の状態が異 ると集落形に差が生ずることが観察された。一般 に，好気的な状態では集落は大型に且つ淡く，わう かに姅気的な状態では, $\mathrm{CO}_{2}$ 濃度の増すにつれて小 さく且つ濃くなる傾向がある.

レプトピラの集落は特徴ある位置に形成される。 すなわち,レプトスピラは寒天培地の表面に植えら れるにもかかわらず，常に培地の内部に向って半球 形に集落をつくり，培地面より上には決して集落を つくらない, 好気性, 嫌気性の別, あるいは培地中 に含まれる寒天の濃度の如何にかかわらず，集落の 形成は常にこの位置でおこなわれる.このことはレ プトスピラ属の特徴のひとつと考えられる．深部培 養ではふつう球形の集落がつくられる.

以上のような成績を得たので，わづかに嫌気的な 状態で培養することは，レプトスピラの集落形成に もっとも必要な条件のひとつと考えられる. 


\section{EXPLANATION OF PLATES}

\section{Plate I}

Fig. 1. Colonies of strain TR-1 (L. icterohaemorrhagiae), 14th day of incubation in $1 \% \mathrm{CO}_{2}$.

Fig. 2. Colonies of strain Saeki ( $L$. autumnalis), 17 th day of incubation in $5 \% \mathrm{CO}_{2}$.

Fig. 3. Colonies of strain Moscou V, 20th day of incubation in closed dishes.

Fig. 4. Section of colonies of strain Saeki, 13th day of incubation in 5\% $\mathrm{CO}_{2}$.

\section{Plate II}

Fig. 5. Colonies of strain Utrecht IV, 20th day of incubation in air (right) and 5\% $\mathrm{CO}_{2}$ (left). Colonies. developed more small in $5 \% \mathrm{CO}_{2}$ than in air.

Fig. 6. Colonies of strain Swart, 20th day of incubation in closed dishes (right) and 10\% $\mathrm{CO}_{2}$ (left). Colonies developed more small in $10 \% \mathrm{CO}_{2}$ than in closed dishes. 


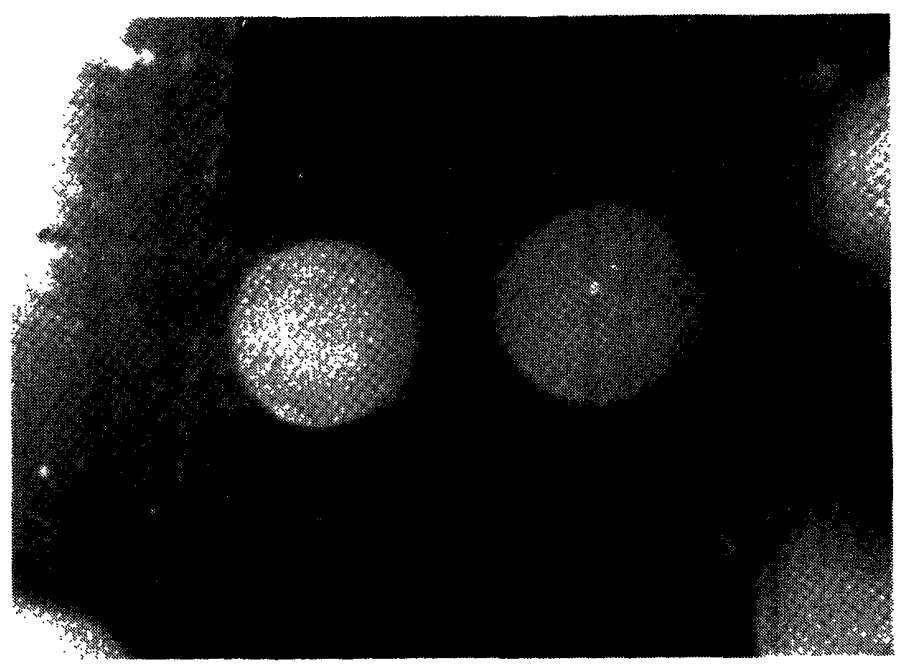

Fig. 1

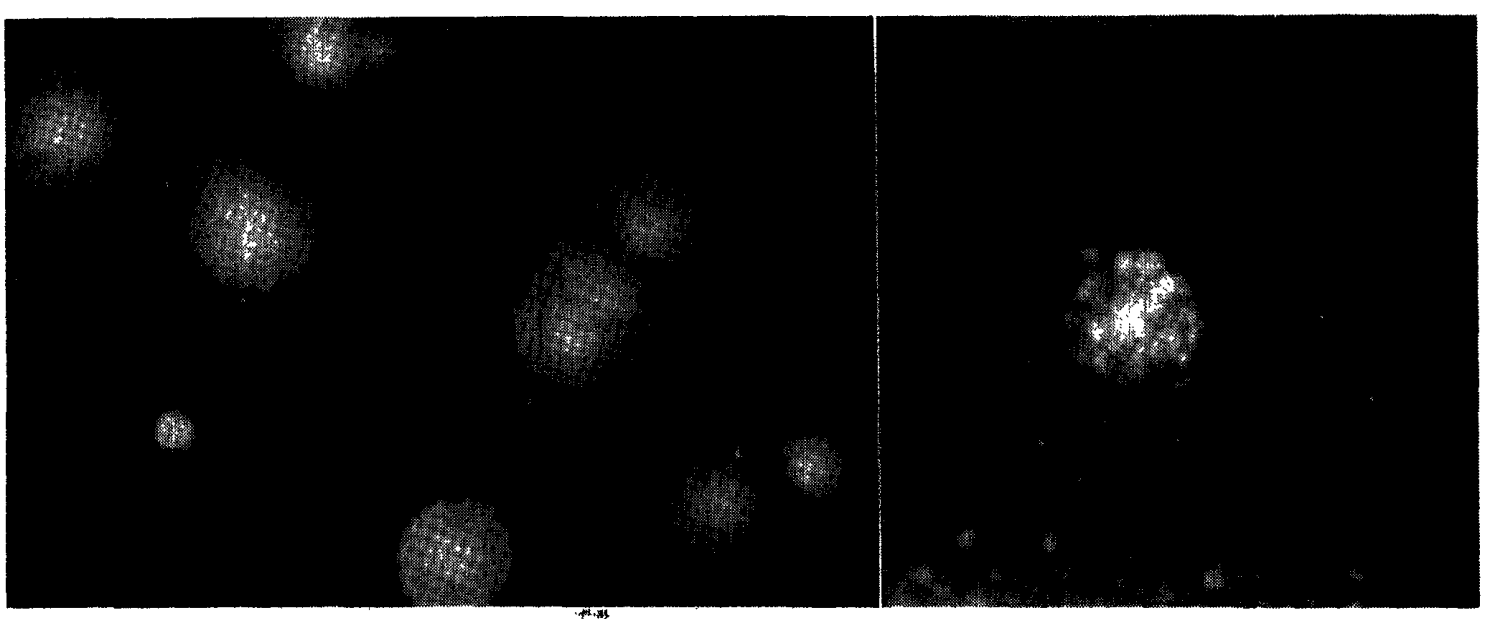

Fig. 2

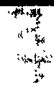

Fig. 3

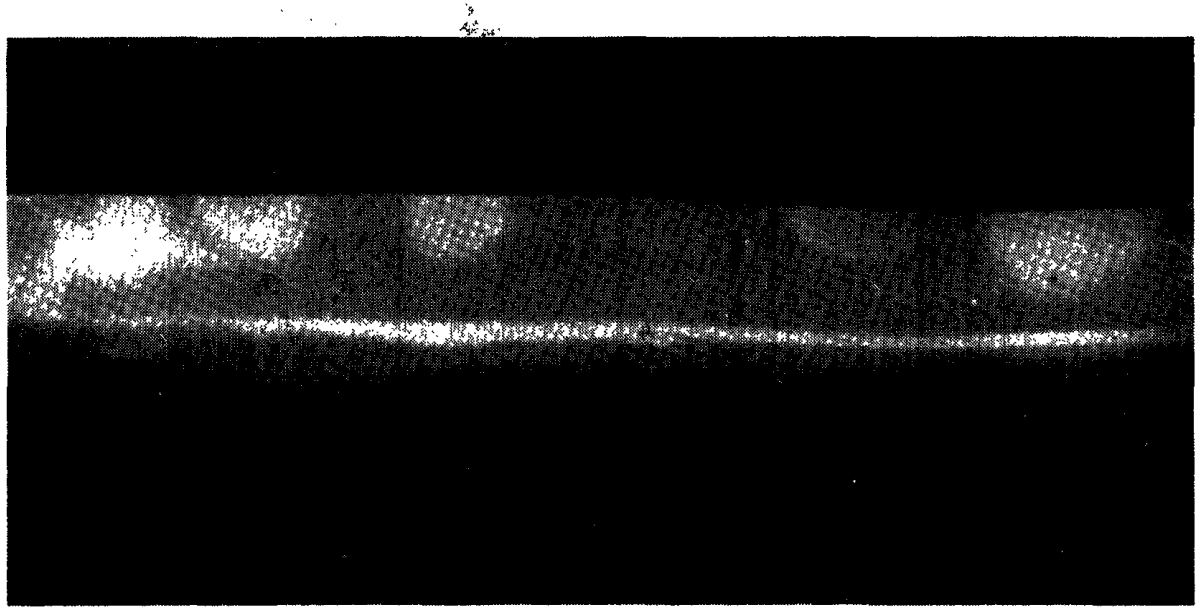

Fig. 4 


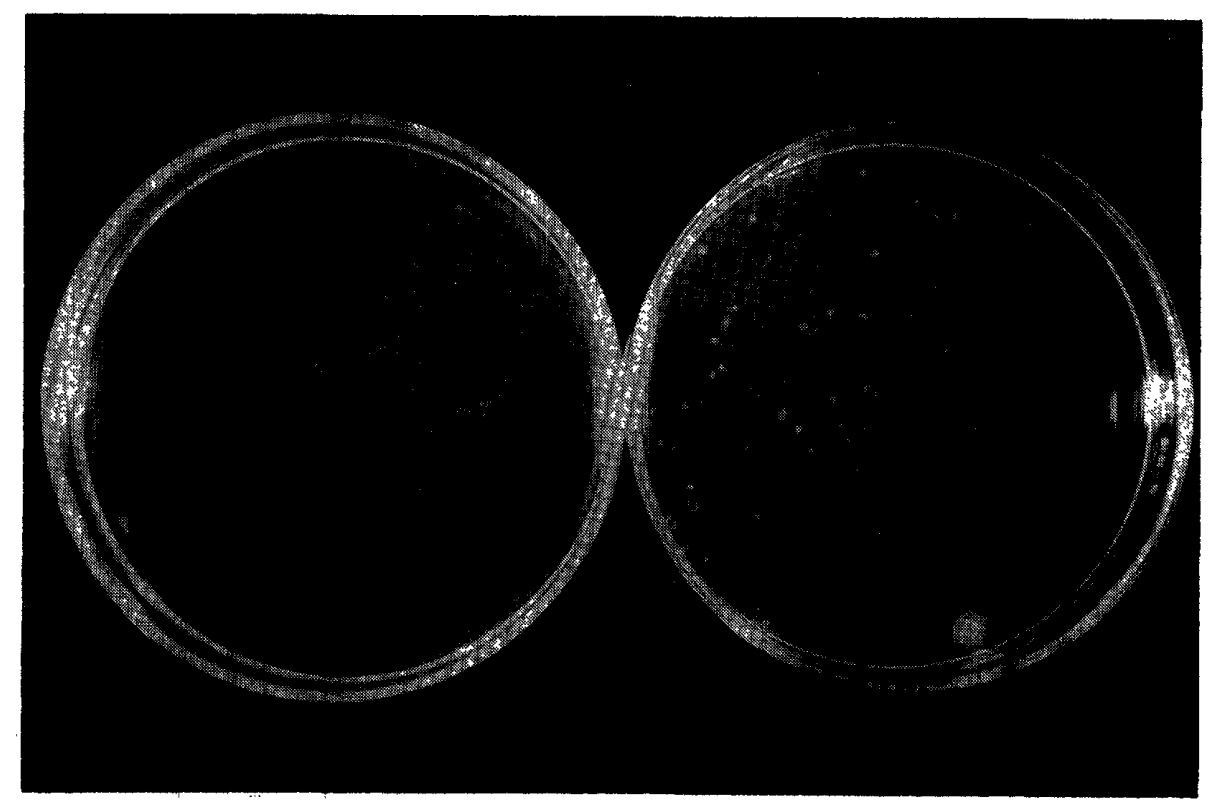

Fig. 5

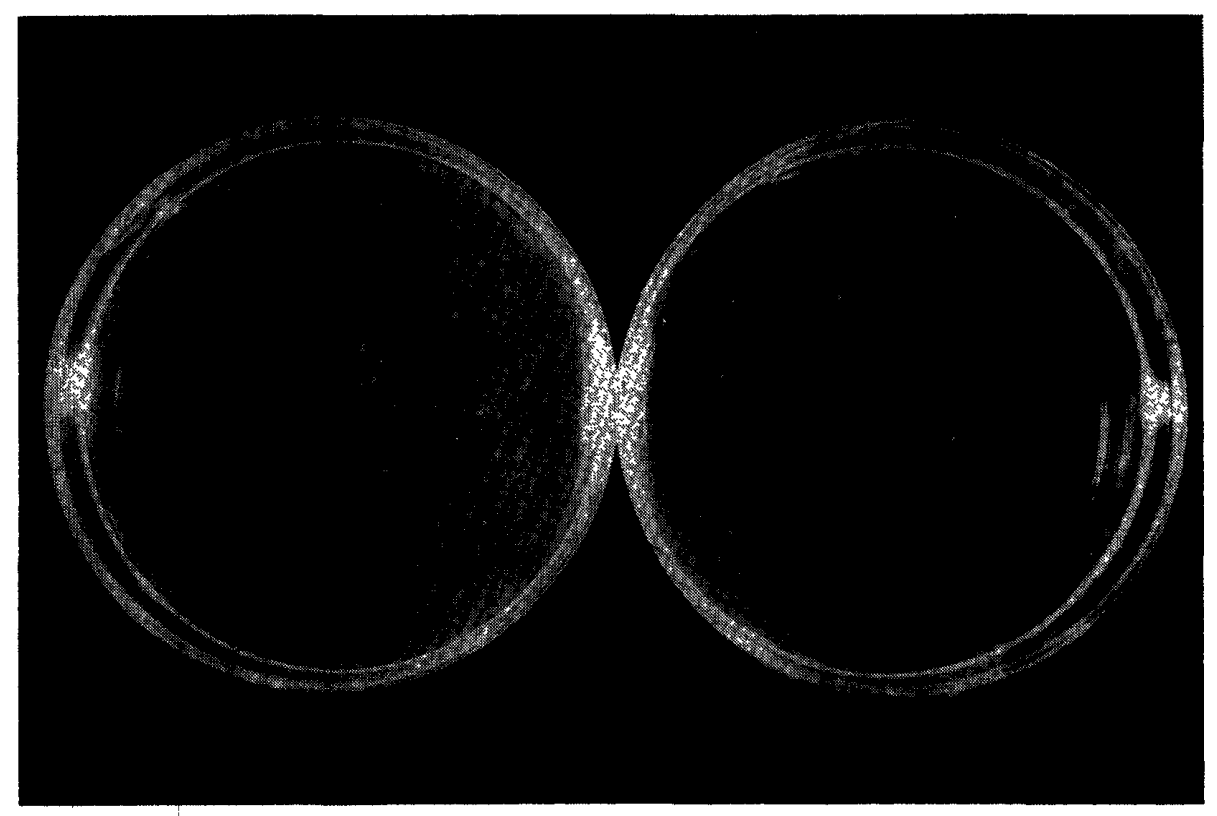

Fig. 6 